\title{
The examples of reverse logistics application in inter-sector partnerships - good practices
}

\author{
Anetta Zielińska \\ Wroclaw University of Economics \\ Poland \\ anetta.zielinska@ue.wroc.pl
}

\author{
Maja Prudzienica \\ Wroclaw University of Economics \\ Poland \\ maja.prudzienica@ue.wroc.pl \\ Ernur Mukhtar \\ Al-Farabi Kazakh National University \\ Kazakhstan \\ Ernur_mukhtar@mail.ru \\ Karlygash Mukhtarova \\ Al-Farabi Kazakh National University \\ Kazakhstan \\ karligash.muhtarova@kaznu.kz
}

Abstract. The interest in the problems of environmental protection and, in particular, retives of various areas of social and economic life understood as intersector cooperation is becoming more and more desirable also in relation to environmental protection.

Reverse logistics begins to be in the centre of activities carried out by inter-sector partnerships, through such actions as reuse of packages, minimising energy consumption and pollution connected with transport and recycling of package discards, among others. This article aims at showing the application of reverse logistics in the activities undertaken within the framework of inter-sector cooperation in Poland, by entities of social economics(social cooperatives). The case study method is applied.

Keywords: reverse logistics, inter-sector partnerships, Social Cooperatives

JEL Classification: R110, H760, L33 


\section{[...] It seems that we are more and more aware that the exploitation of Earth, the planet on which we live on, requires a rational and honest planning}

John Paul II, Redemptorhominis, encyclical announced on 4th March 1979

\section{INTRODUCTION}

Functioning of contemporary society in both economic and social spheres enhances the awareness of striving for life in better conditions and, consequently, constant social and economic development. As a result, faster and faster development of the contemporary world striving for the improvement of living conditions entails a lot of negative phenomena, such as, for example, destruction and degradation of the environment.

The interest in environmental protection and, in particular,in reverse logistics, results primarily from the growing awareness for environmental issues in the society as well as changing legal regulations deriving from the membership of Poland in the European Union, among others.

Solutionsto the problems related to ecology and environmental protection play a vital role at the state level as well as on the level of civil initiatives, private individuals and business representatives. This stems from constantly increasing amount of wastes generated by the society, including municipal waste, among others. Reverse logistics effectively responds to waste management processes. It is an important tool which is the subject of research and much discussion among exports in the fields of environmental protection and logistics,as it ensures well planned and more effective waste flow.

This article aims at showing the application of reverse logistics in the activities undertaken within the framework of inter-sector cooperation in Poland, by entities of social economics(namely, social cooperatives). The case study method is applied.

\section{INTER-SECTOR COOPERATION - THE ESSENCE}

The collaboration of representatives of various areas of social and economic life understood as the intersector cooperation is becoming more and more desirable also in relation to environmental protection. Such partnerships may be initiated by both business entities operating on a for profit basis and non-governmental organizations as well as public institutions which operate at the local, regional, national or even international level. If the idea of partnership convinces and activates as many diversified entities as possible, it increases the chance to develop lasting relationships and implementation of a lot of public purposes, in particular those, in accomplishment of which the rule of partnership is of the utmost importance.

Through inter-sector partnership we understand a joint effort (action) in which entities from various public sector are parties. They join forces in order to solve common social and economic problems visible for all partners.

These partnerships are often quite complicated, mainly due to the fact that they are established to solve complex problems. Furthermore, they are frequently implemented in occurrences that are difficult to foresee and because the participants of such partnerships are entities from various sectors and each of them has a different language, various ways of acting, opposing interests and strategies. Although the knowledge concerning this subject is not new, it has been so far hardly recognised. The more complex factors influencing the actual establishment of partnerships are, the larger misunderstanding of the idea of partnership is. 
Difficulties in understanding the complexity of establishing partnerships are strengthened by the fact that scientific research (Stöteler, Reeder, van Tulder, May 2012, pp. 1-3) often neglects the initial phase of establishing partnerships. So far the majority of the research focuses mostly on two stages of the so-called "partnership cycle": implementation and institutionalization as well as expiration of the partnership. Lately it has been assumed that a lot of failures in functioning of inter-sector partnerships take place in the initiation (exploration) phase, i.e. just at the beginning of establishing partnerships. It results from the fact that in the initiation phase the strategic decisions are taken which concerns the definition of the problem or including and excluding partners, among others. Sometimes decisions are made on the basis of proven, examined and analysed factors. However, more frequently inter-sector partnerships are established when needed, they are intuitive or because in the past there was a partnership which succeeded in solving a given problem (Compare ibid Stöteler, Reeder, van Tulder, May 2012, pp. 1-3).

The research (Compare:Selsky, Parker, 2005; Jørgensen, 2006; Wagner, 2011) on the inter-sector partnership led to distinguishing its four dimensions. The first dimension means partnerships between nonprofit organizations and companies dealing with social issues and reasons of their occurrence. The second dimension means partnerships between public institutions and enterprises. The public-private partnership (PPP) dominates here. It is quite specific and legitimately defined form. In formal sense this is an instrument used still quite rarely, taking into consideration benefits which could result from its application. The third dimension concerns a very interesting concept - the so-called public and private partnership. Nowadays there is no academic definition of this term which is unequivocal and exhaustive. It functions as a description of a certain phenomena, explained for the purposes of particular undertakings. Attempts are being made to define this concept in order to emphasize its distinctiveness from PPP and highlight an essential component of such undertakings, which is the participation of social party, and the provisions of the Act on public benefit authority and volunteerism (The Act of 24th April 2003 on public...) constitute a confirmation of this fact. The fourth dimension means partnerships which concerns joint actions of entities from all three sectors. This dimension focuses on national or international multi-sectoral projects carried out on a large scale but it does not neglect territorial projects.

Over the past few decades in Europe the visible evolution of mutual relations has been noticed. This process is different in different countries depending on social policy models adopted by particular States, but generally everywhere it is possible to distinguish similar phases. The public administration model as the only or even main provider of public services is gradually abandoned. This happens thanks to perceiving the need of deconcentration, privatisation as well as contracting and entrusting public tasks to entities which understand needs of social groups better and represent their interests.

In Poland one can observe all these elements, although it must be noticed that it is a chaotic process in which there is no clear vision of "the allocation of work" between certain institutions and sectors. In many fields the bipolar model dominates:

a) public institutions and business entities (enterprises),

b) non-governmental organisations - enterprises and

c) public institutions and third-sector actors,

d) the "three-pole" model is practically not used at all: public institutions - enterprises - non-governmental organisations

State and public administration often reluctantly delegate tasks to the third sector and often ensure themselves the right of "pre-emption". The deconcentration, in practice of the existing inter-sector partnership, means transferring competencies and public resources which so far have been implemented only and exclusively by state institutions. Nowadays state entities are aware that they are unable to carry out all public and social tasks with which they have been dealing with until now. During delegation of tasks for the 
third sector, the failure in subjecting actions in terms of their efficiency in solving problems frequently takes place. Actions consisting in transferring and "shifting" problems on the third-sector entities are observed. Delegation (commissioning) of tasks to private or social entities lies most of all in striving for decreasing the liability of state and its bodies. Furthermore, the provision of services is entrusted to other entities, the activity of which is based on poorly defined standards, the lack of effective mechanisms for safeguarding their recipients' interests and recognising not a quality of services provided but only the price as a dominant factor when it comes to choosing. As as far as the cooperation with non-governmental institutions (NGOs) is concerned, it is often strongly dependent on public funds, is characterised by subjecting and reducing to the role of "specific" clients. Therefore, on the basis of such relations it is difficult to establish a permanent institution of partnership.

\section{THE CONCEPT OF REVERSE LOGISTICS - THE ESSENCE}

As far as problems with waste management are concerned, reverse logistics is one of the concepts aiming at opposing to the growing amount of waste.

Reverse logistics is the field of ecology-oriented logistics. This is why the concept of reverse logistics may be considered in terms of the border between two scientific disciplines: ecology and logistics. The understanding of reverse logistics requires defining these two components (Brzozowska, 2014, p. 130).

The term ecology comes from the 19th century and means the science concerning relations between people and their living environment. The subjects of research in ecology include: air, water and soil, which are the determinants having the effect on the life on Earth, resources and energy necessary to produce food, clothes and flats as well as waste deteriorating the condition of environment (Brzozowska, 2014, p. 130).

As far as logistics is concerned, it is a process of planning, organising, implementing and controlling efficient and effective flow of resources, materials, production in progress and accompanying services from the place of origin to the place of consumption in order to satisfy customers' needs (Gołembska, 2010, s. 19).

Reverse logistics is an integrated system which (Korzen', 2001, p.16):

- is based on managing the recirculation of waste materials in the economy and information concerning them;

- ensures readiness and ability to store, segregate, process and reuse waste in accordance with the adopted technical and process rules, meeting legal requirements at the same time;

- enables making a decision connected with diminishing negative effects on the environment through logistical processes;

- takes into consideration economic aspects of actions preventing pollution.

The approach to the reverse logistics mostly focuses on "return" flows, i.e.:

- some elements of products which achieved their objectives on the market are reused in the production by the company or

- the whole products which were used by customers and are, for example, recycled.

The concept of integrated sustainable waste management: sustainability in this concept includes the three pillars of sustainability environmental, economic and social. Integrated in this context means all three domains of sustainability (environment, society, economy) addressed, different waste management options are possible (prevention, reuse, recycling, energy recovery, disposal), different habitat scales considered (household, neighbourhood, city, region), various stakeholders involved (formal and informal, profit-oriented and non-profit, large and small, local and national, men and women), both technological issues and non-technological issues addressed (people's attitudes towards waste, ability and willingness to pay, environ- 
mental effects, transparency of institutions, citizen participation, political interventions) and interlinkages with other urban systems (e.g. water supply, drainage, agriculture) considered.

The reverse logistics is connected with the system of comprehensive management of solid waste which comprises four activities (Tchobanoglous, 1994):

1. Reduction at source, which is the most effective way to reduce the amount of waste, the cost associated with handling and environmental impacts. Waste can be reduced through design, production and packaging of products with minimal toxic material, minimum volume of material, longer shelf life and product reuse and materials.

2. Recycling, which involves the separation and collection of waste materials, the preparation of these materials in order to reuse, reprocessing and transformation into new products. reliable and close to the recovered materials in order to have a satisfactory recycling market program is necessary. In addition, recycling programs require collection and processing infrastructure to enable a reliable and consistent supply of recovered material for manufacturers. Among the recovered materials most commonly used in recycling are: aluminum, paper and cardboard, glass, plastics and ferrous materials such as iron and steel (Henry, Heinke, 1999).

3. Transformation of waste through operations that alter its chemical, physical or biological composition. An example of this transformation is the combustion and production of fertilizer.

4. While the management of waste from the point of sustainable view, includes the aspects considered in sustainability are environmental, social and economic aspect and must begin to effect separation of waste at the source thereof and incorparar the recycling and reutilization thereof to minimize the volume of residues in landfills.

For the above reasons reverse logistics aims at emphasizing the meaning of processes related to the waste managements, in particular, such as: the collection of waste, segregation, transport, storage in selected places, processing (Zielińska, 2015, pp. 288-289).

Reverse logistics begins to be in the centre of interest of activities carried out by inter-sector partnerships, through such actions as reuse of packages, minimising energy consumption and pollution connected with transport and recycling of package discards, among others.

\section{EXAMPLES OF GOOD PRACTICES}

In Poland inter-sector partnership is often established in the area of broadly understood environmental protection and ecology. Reverse logistics is not a well-known conception of action and is still underestimated by entities creating inter-sector partnership. However, in actions taken within the framework of partnerships one can notice presumed attempts of its partial assumptions.

Social cooperatives, as entities of social economy, take actions within concluded inter-sector partnerships and they participate in them actively. On the one hand they contribute to increasing their own opportunities of action, on the other they give the profit companies a chance to make their activity ethical and social and the public administration may reduce expenses effectively. In this way social cooperatives gain know-how of business and the support of administration, whereas the partner company obtains the "social value" which influences the good opinion and prestige of the company. For companies entering into this kind of partnership, the social aspect itself (e.g. supporting the employment of excluded individuals) is as important as the advertisement directed to potential customers (social is social but business is business). Therefore, partnerships fit into corporate social responsibility (CSR).

Examples of such undertakings are described in Table 1. 
Examples of reverse logistics application in inter-sector partnerships in Poland

\begin{tabular}{|c|c|c|}
\hline $\begin{array}{c}\text { Name of the undertaking related to } \\
\text { reverse logistics }\end{array}$ & Description & $\begin{array}{l}\text { Names of entities in social economics } \\
\text { undertaking activities within inter- } \\
\text { sector partnerships }\end{array}$ \\
\hline Urban greenery management & $\begin{array}{l}\text { A lot of cooperatives have specialised } \\
\text { in designing green areas and taking } \\
\text { care of urban greenery. The invest- } \\
\text { ments in human capital and a lot } \\
\text { of manual operations are preferred } \\
\text { here. Savings on investments into } \\
\text { expensive devices which pollute the } \\
\text { air, e.g combustion machines, leaf } \\
\text { blowers, lifts and booms for pruning, } \\
\text { etc. Cooperatives employ excluded } \\
\text { individuals and have impact on envi- } \\
\text { ronmental protection. }\end{array}$ & $\begin{array}{l}\text { 1. Spółdzielnia Socjalna „Patron” } \\
\text { in Jelenia Góra } \\
\text { 2. Wielobranżowa Spółdzielnia } \\
\text { Socjalna „PROGRESS” in } \\
\text { Żórawina } \\
\text { 3. Wielobranżowa Spółdzielnia } \\
\text { Socjalna „SIEDEM” in Strzelin } \\
\text { 4. Bolesławiecka Spółdzielnia } \\
\text { Socjalna „BSS” in Bolesławiec } \\
\text { 5. Spółdzielnia Socjalna „RAZEM” } \\
\text { in Radzyń } \\
\text { 6. Spółdzielnia Socjalna } \\
\text { "LAS VEGAS” w Polanowo }\end{array}$ \\
\hline Second hand shops & $\begin{array}{l}\text { It is a kind of ,storeroom" where old } \\
\text { or damaged objects (clothes, technical } \\
\text { devices, books, etc) donated by private } \\
\text { persons, enterprises, libraries have } \\
\text { a chance for recycling. They aim at } \\
\text { minimising waste and pro-ecological } \\
\text { efforts. Furthermore, it is a chance for } \\
\text { the indigent persons to purchase ob- } \\
\text { jects which still work at a low prices }\end{array}$ & $\begin{array}{l}\text { 1. Wielobranżowa Spółdzielnia } \\
\text { Socjalna „BETA” in Świdnica } \\
\text { 2. KUFEREK MODA \& ART } \\
\text { Spółdzielnia Socjalna in Lublin } \\
\text { 3. Spółdzielnia Socjalna „KROK DO } \\
\text { PRZODU” in Kłaj } \\
\text { 4. Spółdzielnia Socjalna } \\
\text { „KOOPERACJA” in Sopot } \\
\text { 5. Spółdzielnia Socjalna } \\
\text { „SZANSA” in Radlin } \\
\text { 6. Spółdzielnia Socjalna } \\
\text { „KRAM” in Lubosz }\end{array}$ \\
\hline Vegetarian catering and Fair Trade & $\begin{array}{l}\text { Cooperatives treated as ecobusiness, } \\
\text { i.e. the management of food service } \\
\text { activities in partnerships with food } \\
\text { producers and restaurants where } \\
\text { the social element is combined with } \\
\text { ecology (vegatarianism, veganism) } \\
\text { and ethics (fair trade). Products used } \\
\text { in preparing vegetarian dishes are rela- } \\
\text { tively little processed so they generate } \\
\text { much less waste and the remaining } \\
\text { waste are further processed. The } \\
\text { enterpreneurship of the cooperative } \\
\text { influences generating new jobs for ex- } \\
\text { cluded individuals which create a high } \\
\text { quality service }\end{array}$ & $\begin{array}{l}\text { 1. Spółdzielnia Socjalna } \\
\text { „AKADEMIA SMAKU” } \\
\text { in Kolbuszowa } \\
\text { 2. Spółdzielnia Socjalna „VITA } \\
\text { SOLIS” in Sowina } \\
\text { 3. Spółdzielnia Socjalna } \\
\text { „VARIA” in Łódź } \\
\text { 4. Spółdzielnia Socjalna } \\
\text { „MARGINES” in Wasaw } \\
\text { 5. Spółdzielnia Socjalna „COR ET } \\
\text { MANUS.JAK U ELI” in Słubice } \\
\text { 6. „STUDIO DOOZO”-the } \\
\text { first social cooperative in Szczecin }\end{array}$ \\
\hline Clean energy & $\begin{array}{l}\text { Social cooperatives collaborate } \\
\text { with producers dealing with energy } \\
\text { services. They carry out their business } \\
\text { activity in assembly of photovol- } \\
\text { taic and solar panels and heat pump } \\
\text { equipment. Furthermore, they offer } \\
\text { BREEAM certification, along with } \\
\text { the possible repair and construction } \\
\text { services (insulation, replacement of } \\
\text { windows) }\end{array}$ & $\begin{array}{l}\text { 1. Spółdzielnia Socjalna „PERON 3” } \\
\text { in Motycz } \\
\text { 2. Krakowska Spółdzielnia Socjalna } \\
\text { "VIFENIX” in Cracow } \\
\text { 3. Spółdzielnia Socjalna } \\
\text { „GRÓD” in Byczyna }\end{array}$ \\
\hline
\end{tabular}

Source: own elaboration on the basis of pursuant to non-public information and own research. 
Currently there are 1321 (www.spoldzielniesocjalne.org) social cooperatives operating in Poland, which to a smaller or larger extent take up activities within formal or in formal inter-sector partnerships. As it is possible to conclude from the information presented in the table above, a slight share (barely 1,6\%) of all operating inter-sector partnerships undertake activities in accordance with the concept of ecologistics. This situation might be a consequence of: a low ecological awareness of entities participating in inter-sector partnerships, for example Social Cooperatives; the lack of knowledge of the principles of ecologistics and potential benefits resulting from its application. Additionally, the necessity to protect the environment, for example as a result of more and more environment pollution and limited possibilities of using natural resources and a dynamic increase of waste, is still overlooked. However, ecologistics is one of the most important concepts conditioning the achievement of economic effectiveness by the entities participating in inter-sector partnerships.

\section{FINAL CONCLUSIONS}

Gained results allow to formulate few conclusions:

- The paper was aimed to show ecologistics activities appearing within inter-sector partnerships. The authors on purpose selected the entities of social economics, Social Cooperatives taking up activities within inter-sector partnerships, to present the examples of the application of ecologistics. Social Cooperatives are entities, which to the greatest extent realized the possibilities of improvement and strengthening its activity by undertaking initiatives and activities within the inter-sector partnership and the application of new trends, such as ecologistics.

- The authors are aware that the issue discussed in the paper is only an extract of the problem and might be the beginning of a discussion, which in view of the economic conditions and changeable environment in which the entities operate, will be a worth continuing.

- Analysis of the Polish experience in the procurement and reverse logistics allows us to offer a number of enhancements for use in Kazakhstan. Improving public procurement mechanisms in Kazakhstan is a topic for future research.

\section{REFERENCES:}

Brzozowska M. (2014), Ekologistyka, [in:] Przedsiębiorczość i Zarzadzanie, Wydawnictwo SAN, tom XV, zeszyt 5, czeşć III, Łódź.

Gołembska E. (2010), Kompendium wiedzy o logistyce, PWN, Warszawa.

Henry J.G., Heinke G.W. (1999), Ingeniería ambiental, Prentice Hall, Mexico.

John Paul II (1979), Redemptorhominis, encyclical announced on 4th March.

Jørgensen M. (2006), Evaluating cross-sector partnerships, Working paper presented at the conference 'Public-private partnerships in the post WSSD context', Copenhagen Business School, August 1.

Korzen' Z. (2001), Ekologistyka, Biblioteka Logistyka, Poznan'.

Selsky J. W., Parker B. (2005), Cross-Sector Partnerships to Address Social - Issues: Challenges to Theory and Practice, Journal of Management, Vol. 31 No. 6, December.

Stöteler I., Reeder S., van Tulder R. (2012), Cross-Sector Partnership Formation -What to consider before you start?, Partnerships Resource Centre, May. 
Tchobanoglous G., Vigil S., Theisen H. (1994), Gestión integral de residuos sólidos,McGraw-Hill Interamericana de España.

The Act of 24th April 2003 on public benefit authority and volunteerism (J. of L., no. 96, item 873, as amended.).

Wagner R.F. (2011), Deepening Research on Cross and Sector Social Partnerships in the Middle East, Workshop Proceedings, NYU Abu Dhabi, UAE, October 24-26.

www.spoldzielniesocjalne.org [date of collection: 10.12.2016]

Zieliniska A. (2015), Ecologistics Activities in Terms of Communal Waste in Poland, [in:] 5th International Youth Science Forum "Litteris Et Artibus", Lviv Polytechnic Publishing House, Lviv,26-28November, Ukraine. 